Vietnam's Children in a Changing World 
The Rutgers Series in Childhood Studies

Edited by Myra Bluebond-Langner

Advisory Board

Joan Jacobs Brumberg

Perri Klass

Jill Korbin

Bambi Schiefflin

Enid Schildkraut 


\section{Vietnam’s Children \\ in a Changing \\ World}

Rachel Burr

Rutgers University Press

New Brunswick, New Jersey, and London 


\section{Library of Congress Cataloging-in-Publication Data}

Burr, Rachel.

Vietnam's children in a changing world / by Rachel Burr.

p. cm. - (The Rutgers series in childhood studies)

Includes bibliographical references and index.

ISBN-13: 978-0-8135-3795-5 (hardcover : alk. paper)

ISBN-13: 978-0-8135-3796-2 (pbk. : alk. paper)

1. Children-Vietnam-Social conditions. 2. Street children-Vietnam.

3. Children's rights-Vietnam. 4. Child labor-Vietnam. 5. Child welfareVietnam. 6. Humanitarian assistance-Vietnam. 7. North and south.

I. Title. II. Series.

HQ792.V5B87 2006

362.7’09597-dc22

2005023052

A British Cataloging-in-Publication record for this book is available from the British Library.

Copyright $@ 2006$ by Rachel Burr

All rights reserved

No part of this book may be reproduced or utilized in any form or by any means, electronic or mechanical, or by any information storage and retrieval system, without written permission from the publisher. Please contact Rutgers University Press, 100 Joyce Kilmer Avenue, Piscataway, NJ 08854-8099. The only exception to this prohibition is "fair use" as defined by U.S. copyright law.

Manufactured in the United States of America 
To Mum and Dad,

with much gratitude and love

And in memory of Father Charlie Robak, who was a great friend and inspiration 
